\title{
Gambaran Distres Psikologis pada Petani Tembakau \\ Di Kecamatan Kalisat Kabupaten Jember
}

\section{(Description of Psichologycal Disstres of Tobacco Farmer in Kalisat District Jember City)}

\author{
Alviolita Nur Septiani, Emi Wuri Wuryaningsih, Enggal Hadi Kurniyawan \\ Fakultas Keperawatan Universitas Jember \\ JI. Kalimantan No. Kampus Tegal Boto Jember 37 Telp./Fax. (0331) 323450 \\ e-mail: emiwuryaningsih.unej@gmail.com
}

\begin{abstract}
Serious problems experienced by tobacco farmers are narrowing land area, decreasing land fertility, degradation of agricultural land, pest attacks, inappropriate fertilization to tobacco plants, weather and crop failure. Those problems posed the tobacco farmers at risk of psychological distress. This study aimed to analyze psychological distress in tobacco farmers in Kalisat, Jember. The design of this study was descriptive analysis with cluster sampling and proportional sampling techniques. The population of this study was tobacco farmers, as many as $91(\mathrm{Cl}=90 \%)$. The research instruments were the 42 Depression Anxiety and Stress Scale questionnaires (DASS 42) (Cronbach's Alpha 0.776; 0.931; 0.803). The results showed that tobacco farmers had the highest anxiety (73.6\%), stress (26.4\%), and depression (11\%). Psychological distress in farmers is manifested in the form of worries and fears of work which is generally due to instability from the work of farmers.
\end{abstract}

Keywords: Psychological Distress, Stress, Depression, Anxiety, Tobacco Farmer

\begin{abstract}
Abstrak
Permasalahan-permasalahan yang serius dialami petani tembakau adalah luas lahan yang semakin menyempit, menurunnya kesuburan lahan, degradasi lahan pertanian, serangan hama penyakit, pemupukan yang tidak sesuai dengan tanaman tembakau, cuaca dan gagal panen berisiko terhadap distres psikologis pada petani tembakau. Penelitian ini bertujuan untuk menganalisis distres psikologis pada petani tembakau di Kecamatan Kalisat Kabupaten Jember. Desain penelitian ini adalah analisis deskriptif dengan teknik pengambilan sampel menggunakan cluster sampling dan proportional sampling. Populasi penelitian ini adalah petani tembakau dengan besar sampel $91(\mathrm{Cl}=90 \%)$. Instrumen penelitian berupa kuesioner Depression Anxiety and Stres Scale 42 (DASS 42) (Cronbach's Alpha 0,776; 0,931; 0,803). Hasil penelitian menunjukkan bahwa petani tembakau memiliki ansietas paling tinggi $(73,6 \%)$, stres $(26,4 \%)$, dan depresi $(11 \%)$. Distres psikologis pada petani diwujudkan berupa kekhawatiran dan ketakutan akan pekerjaan yang pada umumnya karena ketidakstabilan dari pekerjaan petani.
\end{abstract}

Kata Kunci: Distres Psikologis, Stres, Depresi, Kecemasan, Petani Tembakau 


\section{Pendahuluan}

Tembakau adalah salah satu hasil dari pertanian yang secara unik berbahaya bagi kesehatan manusia. Kandungan zat nikotin dan dalam tembakau dapat menyebabkan kecanduan fisik. Karbon monoksida dalam tembakau dapat menarik rangkaian oksigen dalam tubuh sehingga menyebabkan kematian [1]. Sekitar 209,20 $\mathrm{Ha}$ (hektar) dari total keseluruhan areal tanam wilayah Indonesia merupakan tanaman tembakau di tahun 2015 [2]. Provinsi Jawa Timur merupakan provinsi penghasil komoditas tembakau terbesar selain Jawa Tengah dan Nusa Tenggara Barat. Kontribusi tembakau di Jawa Timur mencapai $27 \%$ dari keseluruhan total hasil pertanian. Jawa Timur pada tahun 2016 memiliki luas areal tanam tembakau sekitar 119.206 $\mathrm{Ha}$ dengan produktivitas 0,89 ton/Ha. Jumlah produksi tembakau di Jawa Timur mencapai 42.191 ton pada tahun 2010-2016 [3]. Jember memiliki luas areal panen tembakau sekitar 13.683,50 $\mathrm{Ha}$ dengan produktivitas sekitar 13,00 Kw/Ha. Tahun 2016, kota Jember memiliki angka produksi tembakau sekitar 2.207 Ton [4].

Petani tembakau merupakan individu yang tergabung dalam kelompok usaha tani yang bergerak pada penanaman utama sektor pertanian berupa tembakau. Kegiatan yang dilakukan untuk budidaya tembakau berupa pengolahan tanah, penanaman dan pemupukan, pembubuan dan pengairan, pungel dan wiwit suli, dan pengendalian hama dan penyakit [5]. Permasalahan yang dialami petani tembakau secara sosial adalah luas lahan yang sempit, menurunnya kesuburan lahan, degradasi lahan pertanian, serangan hama penyakit, dan pemupukan yang tidak sesuai dengan tanaman tembakau. Sulitnya pinjaman modal ke perbankan dan lemahnya kemitraan penjualan juga menjadi permasalahan terhadap produksi tembakau [6].

Perbedaan distres psikologis antara pekerjaan pada sektor pertanian memiliki prevalensi lebih tinggi (31,13\%), dibandingkan dengan pekerjaan non pertanian seperti pegawai negeri sipil (PNS) $(30,01 \%)$. Penyebab hal ini karena tunjangan ekonomi, dimana pekerjaan pada sektor pertanian tidak memiliki tunjangan ekonomi untuk masa tua. [7]. Hasil studi menyebutkan, pekerjaan non-petani memiliki kemungkinan penurunan lebih tinggi (25\%-30\%) memiliki gejala depresi dibandingkan dengan pekerjaan petani [8]. Respon distres psikologis diartikan sebagai respon individu yang erat kaitannya dengan perasaan depresi dan ansietas [9]. Pekerjaan petani mempengaruhi distres psikologis yang umumnya diekspresikan dengan depresi dan gejala somatik. Hasil studi menyebutkan bahwa, penyebab bunuh diri pada petani salah satunya adalah distres psikologi [10].

Hasil studi pendahuluan pada petani tembakau didapatkan keluhan yaitu gangguan pada kulit, sakit kepala, mual atau muntah, dan masalah pencernaan. Keluhan lain secara psikologis diantaranya berupa emosi tidak stabil/petani lebih cepat marah, kelelahan, keluhan sakit punggung, dan gangguan tidur. Berdasarkan keluhan tersebut sebagian merupakan bagian dari gejala distres psikologis. Berkaitan dengan permasalahan pada petani tembakau, peneliti perlu mengkaji tentang gambaran distres psikologis pada petani khususnya petani tembakau di daerah Kecamatan Kalisat Kabupaten Jember.

\section{Metode Penelitian}

Metode penelitian ini adalah menggunakan analisis deskriptif. Populasi penelitian ini adalah petani tembakau di Kecamatan Kalisat berjumlah 8.688 responden. Sampel penelitian sebanyak 91 responden. Kriteria Inklusi penelitian ini adalah tergabung dalam Gabungan Kelompok Tani (Gapoktan) di masingmasing desa dan sebagai petani pengelola (pemilik, penyewa, dan bagi hasil). Kriteria eklusi penelitian ini adalah ketika responden yang tidak bersedia untuk menjadi responden penelitian.

Penelitian ini dilakukan di enam desa di Kecamatan Kalisat Kabupaten Jember yaitu desa Sabanen, Sumberkalong, Gumuksari, Ajung, Sumberjeruk, Gambiran. Waktu penelitian dilakukan dimulai bulan September 2018 sampai dengan bulan Mei 2019. Pengumpulan data dilakukan pada bulan Februari 2019. Teknik pengumlan data pada penelitian ini menggunakan kuesioner karakteristik responden dan kuesioner Depression Anxiety and Stres Scale 42 (DASS 42). Instrumen penelitian berupa Depression Anxiety and Stres Scale 42 (DASS 42) yang yang dipublikasikan oleh Psychology Foundation of Australia (2014) dan telah diuji reliabilitasnya dengan dua kali melakukan uji dengan junlah sampel 
144 orang dan didapat nilai stres, ansietas, dan depresi (Cronbach's Alpha $=0,803$; 0,$776 ; 0,931$ ) [11]. Analisis data dalam penelitian ini menggunakan analisis univariat yang sesuai jenis datanya. Analisis data yang digunakan yaitu menggunakan deskriptif statistik. Etika penelitian ini menggunakana prinsip manfaat, hak asasi manusia, dan keadilan. Penelitian ini telah memenuhi uji kelayakan

etik yang dilakukan di KEPK Fakultas

Kedokteran Gigi Universitas Jember berdasarkan 310/UN25.8/KEPK/DL/2019.

\section{Hasil}

Tabel 1. Karakteristik Petani Tembakau

\begin{tabular}{|c|c|c|}
\hline \multicolumn{3}{|c|}{ (Februari 2019, n=91) } \\
\hline $\begin{array}{c}\text { Karakteristik Petani } \\
\text { Tembakau }\end{array}$ & $n$ & (\%) \\
\hline \multicolumn{3}{|l|}{ Usia (Tahun) } \\
\hline Median \pm & & $48 \pm$ \\
\hline Minimal-maksimal & & $\begin{array}{l}45- \\
50\end{array}$ \\
\hline \multicolumn{3}{|l|}{ Jenis kelamin } \\
\hline \multirow{2}{*}{$\begin{array}{l}\text { Laki-laki } \\
\text { Perempuan }\end{array}$} & 59 & 64,8 \\
\hline & 32 & 35,2 \\
\hline \multicolumn{3}{|l|}{ Pendidikan terakhir } \\
\hline SD/ Tidak Sekolah & 58 & 63,7 \\
\hline SMP/ MTs & 12 & 13,2 \\
\hline SMA/ MAN & 18 & 19,8 \\
\hline Perguruan Tinggi & 3 & 3,3 \\
\hline \multicolumn{3}{|l|}{ Penghasilan/bulan } \\
\hline \multirow{2}{*}{$\begin{array}{l}\text { < Rp. } 1.916 .983 \\
\geq \text { Rp. } 1.916 .983\end{array}$} & 75 & 82,4 \\
\hline & 16 & 17,6 \\
\hline \multicolumn{3}{|l|}{ Peran dalam Keluarga } \\
\hline Kepala Keluarga & 56 & 61,5 \\
\hline \multirow{2}{*}{ Istri } & 30 & 33,0 \\
\hline & 4 & 4,4 \\
\hline Orang Tua & 1 & 1,1 \\
\hline \multicolumn{3}{|l|}{ Jumlah Anggota } \\
\hline \multicolumn{3}{|l|}{ Keluarga } \\
\hline \multirow{2}{*}{$\begin{array}{l}\leq 4 \text { orang } \\
>4 \text { orang }\end{array}$} & 69 & 75,8 \\
\hline & 22 & 24,2 \\
\hline \multicolumn{3}{|l|}{ Luas Lahan Pertanian } \\
\hline$\leq 0,65$ Hektar & 80 & 87,9 \\
\hline$>0,65$ Hektar & 11 & 12,1 \\
\hline \multirow{2}{*}{\multicolumn{3}{|c|}{$\begin{array}{l}\text { Catatan: } \mathrm{n}=\text { Jumlah responden; } \%= \\
\text { Persentase }\end{array}$}} \\
\hline & & \\
\hline \multicolumn{3}{|c|}{$\begin{array}{l}\text { Sumber: Data Primer, Februari } 2019 \\
\text { ringan }\end{array}$} \\
\hline $\begin{array}{l}\text { Depresi } \\
\text { sedang }\end{array}$ & 4 & \\
\hline Depresi berat 1 & 1, & \\
\hline
\end{tabular}

Tabel 2. Gambaran Stres pada Petani Tembakau di Kecamatan Kalisat Kebupaten Jember (Februari 2019, $n=91$

\begin{tabular}{|c|c|c|}
\hline $\begin{array}{l}\text { Stres pada } \\
\text { Petani } \\
\text { Tembakau }\end{array}$ & Frekuensi & $\begin{array}{c}\text { Persentase } \\
\text { (\%) }\end{array}$ \\
\hline Normal & 67 & 73,6 \\
\hline Stres ringan & 17 & 7,7 \\
\hline Stres sedang & 15 & 16,5 \\
\hline Stres berat & 2 & 2,2 \\
\hline sekali & & \\
\hline \multicolumn{3}{|c|}{ Sumber: Data Primer, Februari 2019} \\
\hline $\begin{array}{r}\text { Tabel 3. Gam } \\
\text { Temb } \\
\text { Kebu } \\
2019\end{array}$ & $\begin{array}{lr}\text { aran Depres } \\
\text { akau di Keca } \\
\text { aten } & \text { Jemb } \\
n=91) & \end{array}$ & $\begin{array}{l}\text { pada Petani } \\
\text { natan Kalisat } \\
r \quad \text { (Februari }\end{array}$ \\
\hline
\end{tabular}

\begin{tabular}{lll}
\hline $\begin{array}{c}\text { Depresi } \\
\text { pada Petani } \\
\text { Tembakau }\end{array}$ & Frekuensi & $\begin{array}{c}\text { Persentase } \\
(\%)\end{array}$ \\
\hline Normal & 81 & 89,0 \\
Depresi & 5 & 5,5
\end{tabular}

Sumber: Data Primer, Februari 2019

Tabel 4. Gambaran Ansietas pada Petani Tembakau di Kecamatan Kalisat Kebupaten Jember (Februari 2019, n=91)

\begin{tabular}{|c|c|c|}
\hline $\begin{array}{c}\text { Ansietas } \\
\text { pada Petani } \\
\text { Tembakau }\end{array}$ & Frekuensi & $\begin{array}{c}\text { Persentase } \\
(\%)\end{array}$ \\
\hline Normal & 24 & 26,4 \\
\hline $\begin{array}{l}\text { Ansietas } \\
\text { ringan }\end{array}$ & 14 & 15,4 \\
\hline $\begin{array}{l}\text { Ansietas } \\
\text { sedang }\end{array}$ & 30 & 33,0 \\
\hline Ansietas berat & 10 & 11,0 \\
\hline $\begin{array}{l}\text { Ansietas berat } \\
\text { sekali }\end{array}$ & 13 & 14,3 \\
\hline
\end{tabular}

Sumber: Data Primer, Februari 2019

\section{Pembahasan \\ Karakteristik responden}

Hasil penelitian ini menunjukkan usia petani tembakau dalam usia produktif. Usia yang memenuhi syarat untuk bekerja adalah antara 15-54 tahun, karena termasuk dalam usia produktif [12]. Usia erat kaitannya dengan kekuatan fisik. Manusia dengan usia produktif yaitu antara 15-54 tahun lebih mampu untuk bekerja, karena pada usia tersebut kondisi fisik 
masih memungkinkan untuk bekerja. Perawatan tanaman tembakau yang cukup sulit dan menguras energi memerlukan kekuatan fisik yang lebih, sehingga biasanya usia petani tembakau dalam rentan usia produktif. Usia erat kaitannya juga dengan tanggung jawab keluarga dan beban kelurga. Kekuatan fisik erat kaitannya dengan distres psikologis, dimana manusia dengan usia produktif lebih rendah mengalami distres psikologis dari pada usia non produktif.

Berdasarakan hasil penelitian didapatkan bahwa petani tembakau laki-laki lebih banyak jumlahnya dari pada perempuan. Lokasi tempat tinggal biasanya juga akan mempengaruhi gaya hidup masyarakat. Masyarakat desa biasanya mayoritas pekerjaannya adalah petani. Pendidikan petani tembakaau dalam kategori rendah berupa sebagian besar petani tembakau berpendidikan Sekolah Dasar (SD) atau tidak sekolah. Pendidikan formal mempengaruhi pengalaman dan pengetahuan efisiensi teknis bertani, sehingga semakin tinggi pendidikan petani akan berpengaruh terhadap aktivitas dalam mengelola pertanian [13]. pendidikan bagi petani bukanlah hal yang penting dan utama. Hal ini karena para petani berpresepsi jika hanya bekerja sebagai petani tidak perlu untuk memiliki jenjang pendidikan yang tinggi.

Mayoritas petani tembakau yang memiliki penghasilan dibawah Rp. 1.916.983. Penghasilan tersebut menunjukkan bahwa mayoritas penghasilan petani tembakau dalam kategori rendah. Penghasilan petani tembakau kira-kira antara Rp. 1.000.000 hingga Rp. 1.500.000 setiap bulan. Hasil tersebut belum terhitung dengan risiko kegagalan petani tembakau karena hama, atau puso karena kematian atau layu pohon tembakau [14].

Hasil penelitian ini menunjukkan bahwa mayoritas petani tembakau dalam penelitian berperan sebagai kepala keluarga. Hasil menunjukkan jika petani tembakau sebagai kepala keluarga sebagian besar penggarap sawah sepenuhnya adalah kepala keluarga. Adapun istri sebagai mendukung dan membantu suami. Petani tembakau kebanyakan memiliki anggota kurang dari sama dengan 4 orang. Hal ini disebabkan karena beberapa dari keluarga tidak menerapkan sistem keluarga berencana (KB) [15].
Petani tembakau mayoritas memiliki luas lahan kurang dari 1 hektar. Keluarga petani pada luas lahan diatas 0,65 hektar dapat dikatakan keluarga sejahtera [16]. Semakin luas lahan maka hasilnya akan semakin banyak yang berpengaruh pada pendapatan petani. Luas lahan pertanian akan berkaitan dengan kesejahteraan petani tembakau dalam memenuhi kebutuhan karena berkaitan dengan pendapatan. Ketercukupan ekonomi berkaitan dengan distres psikologis petani tembakau.

\section{Gambaran distres psikologis pada petani tembakau}

Hasil penelitian ini menunjukkan bahwa, sejumlah 91 petani tembakau memiliki distres psikologis berupa indikator ansietas paling tinggi $(73,6 \%)$ dilanjutkan dengan indikator stres $(26,4 \%)$ dan depresi (11\%). Petani memiliki risiko distres psikologis lebih tinggi lebih tinggi $(1,12 \%)$ dari pada pekerjaan di bidang sektor non pertanian. penyebab distres psikologis pada petani adalah ketegangan atau keterbatasan ekonomi dan kelelahan fisik. Penyebab ini merupakan kontribusi terhadap stres yang dialami oleh petani [17]. Petani tembakau mengalami distres psikologis karena sifat pekerjaan dengan penghasilan cenderung tidak stabil (setiap masa panen).

Petani tembakau mayoritas tidak mengalami stres (normal). Petani tembakau pada dasarnya rentan mengalami stres karena pekerjaannya maupun faktor lainnya. Faktor utama penyebab stres pada petani tembakau adalah faktor ekonomi dan kondisi keluarga. Usia petani tembakau mempengaruhi kondisi stres, dimana pada usia produktif memiliki stres lebih rendah. Hal ini dikarenakan kondisi fisik yang masih mampu untuk melakukan segala pekerjaan. Umumnya petani tembakau memiliki keyakinan positif utamanya aspek spiritualitas. Aspek ini berupa keyakinan terhadap kehidupannya kepada Tuhan. Stres yang dialami petani tembakau berupa perasaan gelisah, tegang, dan bereaksi berlebihan terhadap sesuatu.

Pekerjaan petani biasanya akan mengandalakan kondisi iklim yang berhubungan dengan cuaca untuk keberhasilan panennya. Kondisi hasil pertanian berpengaruh terhadap kesehatan psikologis petani. Hasil penelitian 
ditemukan perubahan iklim menyebabkan penurunan hasil pertanian yang menjadi berakibat depresi dan bunuh diri pada petani [18]. Depresi merupakan salah satu faktor penyebab kematian pada petani $(11 \%)$. Namun pekerjaan sebagai petani memiliki memiliki risiki lebih rendah untuk mengalami depresi [19]. Petani tembakau memiliki mekanisme koping positif untuk mengendalikan kondisi psikologisnya utamanya depresi. Kasus minoritas ditemukan petani tembakau mengalami depresi. Hal ini disebabkan karena biasanya petani tembakau tidak berharap berlebihan terhadap hasil penennya. Tanda dan gejala depresi yang dialami biasanya berupa merasa pergerakan melambat dari biasanya, perasaan sedih, dan tidak antusias dalam hal apapun.

Hasil penelitian ini menunjukkan bahwa mayoritas petani tembakau mengalami ansietas. Petani memiliki ketakutan terhadap masa depan, karena ketidakstabilan kehidupan. Hal ini dianggap akan mempengaruhi gaya hidup nantinya, jadi biasanya hanya orang dengan usia lanjut yang bekerja sebagai petani. Apabila dengan usia masih muda dengan kekuatan fisik yang dimiliki lebih memilih untuk bekerja selain petani. Hal ini dikarenakan ketakutan akan perekonomian yang tidak stabil jika bekerja sebagai petani [20]. Ansietas yang dialami petani tembakau meliputi kondisi tanaman tembakau dan harga jual. Keluhan lain berupa ketakutan tidak dapat memenuhi kebutuhan ekonomi akibat kegagalan panen. Tanaman tembakau menjadi salah satu tanaman kebanggaan bagi para petani. Tanda dan gejala yang dialami petani tembakau berupa perasaan khawatir, sulit berkondentrasi, dan berada pada situasi cemas.

\section{Simpulan dan Saran}

Petani tembakau sebagian besar usia produktif, berjenis kelamin laki-laki, berpendidikan rendah, mayoritas petani tembakau memiliki penghasilan yang dalam kategori rendah, berperan sebagai kepala keluarga dengan jumlah keluarga kurang dari empat orang, dan luas lahan pertanian kurang dari standar keluarga sejahtera. Gambaran distres psikologis pada petani tembakau paling tinggi ansietas dilanjutkan dengan stres dan depresi.

Pelayanan kesehatan diharapkan dapat melakukan upaya preventif untuk manajemen distres psikologi pada petani tembakau. Pelayanan kesehatan dapat melakukan penyuluhan kepada masyarakat terkait manajemen distres psikologis berupa teknik relaksasi seperti nafas dalam, relaksasi otot progresif atau teknik relaksasi lainnya untuk mengurangi dampak dari distres psikologis.

\section{Daftar Pustaka}

[1] Abidin NA, Brahmaputra M, Kartono M, Widyastuti W, Yudanarso D. Tembakau: ancaman global. Jakarta: Gramedia; 2009.

[2] Badan Pusat Statistik. Luas areal tanaman perkebunan rakyat menurut jenis tanaman, 2000-2015. Jakarta: Badan Pusat Statistik; 2018. [cited 2018 Okt 15]. Available from: https://www.bps.go.id/

[3] Badan Pusat Statistik Provinsi Jawa Timur. Analisis data tembakau Provinsi Jawa Timur 2016. Jawa Timur: Badan Pusat Statistik Provinsi Jawa Timur; 2018. [cited 2018 Okt 15]. Available from: https://www.bps.go.id/

[4] Badan Pusat Statistik Kabupaten Jember. Kabupaten Jember dalam angka: Jember regency in figure 2018. Jember: Badan Pusat Statistik; 2018. [cited 2018 Okt 15]. Available from: https://www.bps.go.id/

[5] Ali M, Bambang W H. Teknik budidaya tembakau. [cited 2018 Sep 24]. 2018. Available

from:https://doi.org/10.31219/osf.io/z y3eb

[6] Setiawan A. Permasalahan agribisnis tembakau di tingkat petani. Prosiding Lokakarya Nasional Agribisnis Tembakau; 2008. [cited 2018 Okt 6]. Available from: http://balittas.litbang.pertanian.go.id/i mages/pdf/sby89.pdf.

[7] Feng D, Ji L, Xu L. Effect of subjective economic status on psychological distress among farmers and non-farmer of rural China. Australian J. Rural Health. 2015; 23(4): 215-220.

[8] Torske MO, Bjørngaard JH, Hilt B, Glasscock D, Krokstad S. Farmers' mental health: a longitudinal sibling comparisonthe hunt study, Norway. Scandinavian journal of work, environment \& health. 42(6): 547-556. 2016.

[9] Feng D, Ji L, Xu L. Effect of subjective economic status on psychological distress among farmers and non-farmers of rural China. Australian Journal of Rural Health. 23(4): 215-220. 2015. [update $2015 \mathrm{Feb}$ 18; cited 2018 Sep 9]. Available from: scihub.tw/10.1111/ajr.12187

[10] Bhise MC, Behere PB. A case- control study of psychological distress in survivors of farmers' suicides in wardha district in central India. Indian journal of psychiatry. 
58(2): 147. 2016. [update 2016 Apr- Jun; cited 2018 Sep 12]. Available from: www.indianjpsychiatry.org

[11] Siagian PCR. Gambaran tingkat stres, ansietas dan depresi pada pasien penyakit jantung koroner di rsup haji adam malik Medan. Skripsi. Universitas Sumatra Utara: Fakultas Keperawatan. 2016. [cited 2019 Jan 10]. Available from:

http://repositori.usu.ac.id/handle/123 $456789 / 2906$

[12] Badan Pusat Statistik. Analisis Kebijakan Pertanian Indonesia: implementasi dan dampak terhadap kesejahteraan petani dari perspektif sensus pertanian. Jakarta: Badan Pusat Statistik: 2014. [cited 2019 Feb 22]. Available from: https://www.bps.go.id/

[13] Estariza E, Prasmatiwi FE, Santoso. Efisiensi produksi dan pendapatan usahatani tembakau di Kabupaten Lampung Timur. Jurnal IImu-IImu Agribisnis. 1(3): 264-270. 2013. [update 2013 Jul; cited 2019 Mar 5].

[14] Ahsan A, Panpan AF, Badrun N, Nur HW, Purwanto TW. Kondisi petani tembakau di indonesia: studi kasus di tiga wilayah penghasil tembakau. Laporan Akhir. Jakarta: Fakultas Ekonomi Universitas Indonesia. 2008. [update 2008 Okt; cited 2019 Mar 10]. Available from: https://www.researchgate.net/publica tion/301197300_KONDISI_PETANI_ TEMBAKAU_DI_INDONES̄IA_Studi_ Kasus_di_Tiga_Wilayah_Penghasil_ Tembakau.
[15] Nuraini N, Achmad A, Budijanto. Analisis kualitas hidup petani pangan di Desa Dringu Kecamatan Dringu Kabupaten Probolinggo. Universitas Negeri Malang. 2013. [cited 2019 Mar 10]. Available from: http://jurnal-

online.um.ac.id/data/artikel/artikelD5

BBEEA61577E6A392CB33F29521D FB9.pdf

[16] Susilowati SH, Maulana M. Luas Iahan usaha tani dan kesejateraan petani: eksistensi petani gurem dan urgensi kebijakan reforma agraria. Analisis Kebijakan Pertanian. 10(1): 17-30. 2016. [update 2012 Feb 13; cited 2019 Jan 12]. Available from: http://ejurnal.litbang.pertanian.go.id/i ndex.php/akp/article/download/3976/ 3312

[17] Feng D, Ji L, Xu L. Effect of subjective economic status on psychological distress among farmers and non-farmers of rural China. Australian Journal of Rural Health. 23(4): 215-220. 2015. [update 2015 Feb 18; cited 2018 Sep 9]. Available from: scihub.tw/10.1111/ajr.12187

[18] Ellis NR, Albrecht GA. Climate change threats to family farmers' sense of place and mental wellbeing: a case study from the Western Australian Wheatbelt. Social Science \& Medicine. 175: 161-168. 2017.

[19] Guillien A, Laurent L, Soumagne T, Puyraveau M, Laplante JJ, Andujar P, Annesi-Maesano I, Roche N, Degano B, Dalphin JC. Anxiety and depression among dairy farmers: the impact of COPD. International journal of chronic obstructive pulmonary disease. 13:1. 2018. 